\title{
Do Active Labor Market Policies Increase the Subjective Well-being of the Unemployed? Evidence from OECD Countries
}

\author{
Marwa SAHNOUN-Chokri ABDENNADHER*
}

\begin{abstract}
The employment policies, whether preventive (Active) or curative (Passive), arouse the interest of policy makers in the OECD countries. These policies are mainly concerned with the economy of labor market, but they are not detachable from the reference to the health economy in its social and psychological dimension. Using different estimates (OLS, FE, GMM system), we found evidence that Active Labor Market Policies (ALMPs) have the strongest impact on the subjective well-being of the unemployed. Examination of the different types of ALMP reveals heterogeneity; programs of incentive employment, start-up incentives and training have been most effective in improving the well-being of the unemployed compared to those of direct job creation and supported employment and rehabilitation. Then, we propose some policy recommendations by emphasizing the disposition of the subjective well-being approach in the design, implementation and evaluation of ALMPS.
\end{abstract}

Keywords: Active Labor Market Policies, subjective well-being, types of ALMPs, OECD countries

JEL Classification: J08, J68, I38

DOI: https://doi.org/10.31577/ekoncas.2021.05.01

\section{Introduction}

The recent years have shown growing interest for what it has been agreed to call the proposed Active Labor Market Policies (ALMP) as a means of combating the persistence of unemployment in the OECD countries. ALMPs are an important area of social policy development, which has prompted international

\footnotetext{
* Marwa SAHNOUN - Chokri ABDENNADHER, University of Sfax, Faculty of Economics and Management, Unit of Research C.O.D.E.C.I, Airport Road Km 4, Sfax 3018, Tunisia; e-mail: marwa.sahnoun1@gmail.com; chokri_abdennader@yahoo.fr
} 
agencies to develop an active approach to employment policy (Goulas and Zervoyianni, 2018). As ALMPs put financial pressure on policymakers, it is therefore of vital interest for society to determine if they reach their estimated goals on the job prospects of the unemployed. That's the reason for which increasing awareness of the need to develop scientifically justified measures of ALMP effectiveness has become a key element in OECD employment policy guidelines. However, abundant literature has been devoted, as we know, to ALMP assessments that have been largely focused exclusively on more concrete outcomes such as unemployment rate, employment rate, wage levels, etc. (Card, Kluve and Weber, 2010; Kluve, 2010; Forslund, Fredriksson and Vikström, 2011; Martin, 2015; Escudero, 2018; Hur, 2019; Sahnoun and Abdennadher, 2018a; 2018b; $2020 ; 2021)$. To track progress, inform and evaluate employment policies, governments are attempting to consider the use of subjective welfare measures. In this context, research has started to focus on the impact of ALMPs on social and psychological consequences of the well-being of the unemployed (Clark and Oswald, 1994; Waddell and Burton, 2006; Dolan, Peasgood and White, 2008; Helliwell, Layard and Sachs, 2016; Rose, 2019). Several studies have been attributed to the measure of well-being as a latent multidimensional concept (Dolan, Peasgood and White, 2008; Diener and Ryan, 2009; Dolan and Metcalfe, 2012; Alatartseva and Barysheva, 2015) and have thus identified key factors that influence well-being such as income, employment, health, demographic and unemployment (Clark and Oswald, 1994; Waddell and Burton, 2006; Blanchflower and Oswald, 2008; Dolan, Peasgood and White, 2008; Ballas and Tranmer, 2012; Deeming, 2013). Traditionally, theoretical and empirical evidence are examined and argue that unemployment or lack of work influences the health and well-being of the unemployed. One of the objectives pursued by the ALMPs would be to reduce the welfare losses for the unemployed. However, the pursuit of such an objective does not fit perfectly with the lessons of wage formation models. In particular, theories of wage bargaining explained why wages are no longer a variable of market forces adjustment, the induced unemployment was being the result of a negotiated salary higher than that which would prevail in an economy without collective actors. In the same way, efficiency wage theories showed how information asymmetry coupled with off-market incentive pay explains the persistence of involuntary unemployment and argued by extension in favor of economic policies to combat unemployment. In theories of wage bargaining and the theories of wage efficiency, a double lack of coordination is at the root of unemployment, a defect that can be remedied through special employment policies that may indirectly reduce welfare losses for the unemployed. Indeed, activation policies have been developed as a means of combating the noxious social effects 
associated with unemployment in British literature (Sage, 2015a). Through ALMPs, jobseekers focus on professional activities by helping them to solve the problem of skills or skills obsolescence, gaining work experience and having a structured day (Strandh, 2001; Andersen, 2008; Daguerre and Etherington, 2009; Carter and Whitworth, 2017). In addition, ALMPs can help the unemployed to maintain their human capital, improve their position in the queue for access to jobs. Several theories have been developed to detect the role of unemployment and ALMPs in the well-being of individuals. For example, the theory of deprivation developed by (Jahoda, Lazarsfeld and Zeisel, 1971; Jahoda, 1982) which reinforced the role of ALMPs on the well-being of the unemployed. This theory is based on 5 functions of work, such as, realization of the structure of time, social contacts, commitment to activities aimed at collective goals, status and identity and regular activity.

If the concept of active labor market policies refers to a myriad of effects on the well-being of the unemployed, the need for a theory that explains why and how unemployment has negative psychosocial effects is being felt. Such a relationship may be derived from particular studies that have been marked by evidence of some social aspects of unemployment (health, well-being, social exclusion). First, one of the arguments for health is that unemployment can lead to harmful diseases, such as, suicide and depression in the fields of epidemiology, psychology and sociology (Stuckler et al., 2009; Jefferis et al., 2011; Norström and Grönqvist, 2015). However, other studies found that there is no relationship between psychological health and employment (McKee-Ryan et al., 2005; Wanberg, 2012). They argued that higher combined levels of depression, anxiety and stress are positively related to job search success. Second, the starting point for welfare research is that the environment of unemployment is detrimental to the well-being of the unemployed. Such a relationship is not only related to income loss, but unemployment has negative psychosocial effects regardless of personal income (Eichhorn, 2014). Another argument is that unemployment affects the well-being of the unemployed in different ways and depends on context and identity (Paul and Moser, 2009; Strandh et al., 2013; Knabe, Schöb and Weimann, 2016). Often depression and "shame" are advanced as arguments in favor of unemployment. On the one hand, several authors (Bolton and Oatley, 1987; Wadsworth, Montgomery and Bartley, 1999; Broom et al., 2006; Jefferis et al., 2011) showed a link between unemployment and depression. Indeed, Jefferis et al. (2011) conducted a study in seven countries and showed that the unemployed have a significantly higher odds-to-depression ratio than those who worked. On the other hand, unemployed people are ashamed of their professional status because this latter constitutes a determining factor of happiness. According to (Eales, 1989), there is a close link between shame and states of depression and anxiety, suggesting the 
probability of a cause-and-effect relationship. Finally, other psychosocial costs of unemployment can be achieved, that is, unemployment has an impact on the life satisfaction (Clark and Oswald, 1994; Lucas et al., 2004; Paul and Moser, 2009; Wulfgramm, 2011a,b; Young, 2012) which can be explained by the lack of social interactions. Considering the social exclusion that refers to social isolation, ${ }^{1}$ the lack of support networks and low social capital, Jahoda et al. (1971) are the first discoveries of this phenomenon. They showed how the unemployed are completely excluded from community life which worsens their social life and gives them feelings of predominance of resignation and apathy. According to Knabe, Schöb and Weimann (2016), unemployment can affect an individual's sense of identity i.e. their perception of belonging to a specific social group and, consequently, feelings of personal happiness and subjective well-being.

ALMPs lead to increasing unambiguously the well-being of the unemployed. However, not all types of ALMPs are associated with such positive effects on well-being i.e. some may improve the experience of unemployment and others not. Lindsay, McQuaid and Dutton (2007) and Bonoli (2010) argued that ALMPs are not homogenous policies but certainly they differ according to their objectives, actors and instruments. In fact, active employment policies refer to a very wide range of programs: public employment services, training, subsidized employment, direct job creation and "start-ups" to increase the demand for labor and measures targeting groups facing particular labor market difficulties (young people, people with disabilities, unskilled low-skilled workers, low-skilled employees). ${ }^{2}$ These different measures of ALMP constitute heavily different types of intervention which allows us to believe that there may be differential effects on the well-being of the unemployed.

The current paper estimates the effectiveness of ALMPs participants on the subjective well-being of the unemployed. Despite the empirical literature of the effects of active labor market policies and the subjective well-being of the unemployed usually uses individual data, we can mobilize macroeconomic variables to express individual preferences. ${ }^{3}$ Macroeconomic variables certainly affect subjective well-being. The variables at the aggregate level are a major concern as survey data has been merged with total public expenditure on ALMPs at the macro level as well as a number of control variables (Lanau et al., 2020). Also, the use of aggregated data presents the interest of concerns about market output and employment, so it is important to focus on welfare as there seems to be

\footnotetext{
${ }^{1}$ Pholan (2019).

${ }^{2}$ Card, Kluve and Weber (2010), Kluve (2010), Puig-Barrachina et al. (2020).

${ }^{3}$ We thank the editors for raising this point "While causality between active labor market policy and subjective well-being is intuitive on the individual level, it is less so on the aggregate level".
} 
a growing gap between the information contained in aggregate GDP data and what matters to the well-being of ordinary people (Stiglitz, Sen and Fitoussi, 2009). In addition, the argument cannot be separated from certain works, in particular the theory of wage negotiation (e.g. the union is a macro organ for the collective expression of individual preferences in the labor market)."

We provide a better understanding of the relationship between ALMPs and well-being and on the other hand a distinction between different ALMP programs, make possible a more detailed analysis of the impact of participation in these programs on the well-being. Each type of ALMP can work across different channels and raises a question: Are there any programs who are carriers of wellbeing than others? In our analysis, we used different estimates (OLS, FE, GMM system) of 29 OECD countries covering a period from 2005 to 2016.

The remainder of this paper is organized as follows. Section 1 shows the literature review. Section 2 discusses the method used for the empirical analysis and presents the database. Section 3 reports the interpretation and discusses the empirical results. Section 4 checks the robustness of our results, and finally, we conclude.

\section{Literature Review}

In social science research (Nordenmark and Strandh, 1999; Gallie and Paugam, 2000; Ritchie, Casebourne and Rick, 2005; Paul and Moser, 2009), some mechanisms (economic i.e. socio-economic class, income, financial insecurity; demographic i.e. work history, sex; education, age, family) have been formed the social experience of unemployment. However, Active Labor Market Policies as a form of welfare interventions have appear to be another approach to change the experience of unemployment. According to Rose (2019), the well-being can be seen as a pertinent predictor of the objective success of ALMPs. Indeed, empirical studies indicate that ALMPs have mixed results on the well-being (Coutts, Stuckler and Cann, 2014). The idea that ALMPs can have positive effects on the well-being can be traced back to essential to the works of (Donovan et al., 1986; Korpi, 1997; Creed, Machin and Hicks, 1999; Strandh, 2001; Andersen, 2008; Wulfgramm, 2011a; 2011b; Krause, 2013; Sage, 2015a,b; Carter and Whitworth, 2017; Rose, 2019; Ivanov, Pfeiffer and Pohlan, 2020; Puig-Barrachina et al., 2020). At the national level, several studies have been developed showing a positive effect of ALMP on the well-being; Vinokur et al. (2000) and Vuori et al. (2002) in USA and Finland, Creed, Bloxsome and Johnston (2001) in Australia, Behle (2005) and Wulfgramm (2011a; 2011b) in Germany, Hagquist and Starrin (1996), Korpi (1997) and Strandh (2001) in Sweden, Anderson (2008) and Bonin 
and Rinne (2014) in Serbia. On the one hand, Creed, Bloxsome and Johnston (2001) showed that training courses specifically designed from the Cognitive Behavioral Therapy (CBT) model improved participants' well-being compared to their peers. Indeed, Strandh (2001) seeked to explore the relationship between labor market policy measures and the mental well-being of the unemployed in Sweden, and showed that only the type of ALMP "participation in the workplace" has had a clearly positive effect on participants' mental well-being. The authors (Creed, Bloxsome and Johnston, 2001; Strandh, 2001) witnessed their results by Johada's theory which predicts that workplace programs fulfill the psychosocial functions of employment. Wulfgramm (2011a; 2011b) found that the activation of ALMP can at least mitigate to some extent the negative effect of unemployment on the life satisfaction in Germany. Indeed, he showed that work placements have strong positive effects on well-being if participants perceive it as relevant to their personal skills and increase their chances of finding a job, but this effect disappears if participants perceive it as degrading. On the other hand, the results also provide explanations for the fact that participants are less satisfied than their regularly employed counterparts. Besides, he found a positive relationship of a German public works program (One-Euro-jobs) on the subjective feeling of social inclusion. However, Gundert and Hohendanner (2015) does not confirm this relation.

In addition, Wulfgramm (2014) analyzed jointly the moderating effects of active and passive labor market policies on subjective well-being in 21 European countries by applying the multi-level method and panel data estimation. The results revealed that passive policies have more moderate effects than ALMPs on the well-being of the unemployed. He explained this result by the fact that labor market policy affects people's satisfaction through a non-monetary mechanism linked to the stigmatization and the position of the unemployed in society. In their scoping review methodology during the period 1990 - 2017 in high-income countries, Puig-Barrachina et al., (2020) found that active labor market policies have a positive impact on health and well-being. Job search assistance type of ALMP has shown a positive effect with no controversy. Furthermore, another recent study conducted by (Ivanov, Pfeiffer and Pohlan, 2020) using a linked survey and administrative data for participants and a group of matched non-participants, the authors analyzed the effects of a German Job Creation Program (JCS) on the social integration and well-being of the unemployed and found significant positive effects of being employed.

Audhoe et al. (2010) conducted a meta-analysis of 29 studies covering the period from 1990 to 2008 seeking to validate the link between participation on ALMPs and well-being. Their results are found to be mitigated; some ALMPs 
have been successful in improving well-being, while few others have improved mental health and re-employment. Moreover, using a British household panel survey from 1991 to 2003, Anderson (2008) found that current and previous participation in government training has a positive effect on subjective wellbeing, although the effect of previous participation decreases over time. Besides, Anderson (2009) analyzed data collected in 17 European countries and showed that unemployed people in countries with higher active labor market policies report more frequent social interactions and a reduced sense of social exclusion. $\mathrm{He}$ also found that individuals who are labor market outsiders have a strong interaction between ALMPs and social ties.

Furthermore, Sage (2013) showed the importance of activation policies in improving the qualitative psychosocial environment of unemployment and indicated the causal link between unemployment and poor health, low well-being and social exclusion. Moreover, Sage (2015a) used a number of linear regression models in the United Kingdom to show that active employment policy programs actually improve the well-being of the unemployed. The author claims that the result varies according to the type of ALMP and by sex; men seem to have the beneficial effect of ALMPs more than women while work-oriented are more effective than the program of employment assistance. Besides, Sage (2015b) carried out the first longitudinal study of well-being in the UK that incorporates new Understanding Society (USoc) data and showed that participation in Active Labor Market Policies is associated with improved well-being for the unemployed and reinforces economic results of training programs while there is no effect of ALMPs on health or social capital.

As we have mentioned above that ALMPs differ in several types according to their natures and objectives, Peck and Theodore (2000) and Lindsay, McQuaid and Dutton (2007) considered the distinction between two types: the human development of capital where the programs practice services to improve skills and personal development and work first that facilitate the return to employment. In addition, Strandh (2001) opted different types of ALMPs: vocational training, workplace participation and work experience schemes.

Different types of ALMP can be implemented, mainly: job search, training, subsidized public employment, subsidized private employment, self-employment assistance and start-up (Card, Kluve and Weber, 2010; Kluve, 2010; Puig-Barrachina et al., 2020). In a study carried out about the links between the variation of Work Program activation effects and well-being in the UK's, Carter and Whitworth (2017) showed that the "thicker" workplace activation policies offer benefits in terms of well-being compared to the open unemployed, unlike the "thinner" activation interventions. 
Table 1

Summary of the Existing Empirical Research

\begin{tabular}{|c|c|c|}
\hline \multicolumn{3}{|c|}{ Some social aspect of the unemployment } \\
\hline Dimensions & Authors & Results \\
\hline Health & $\begin{array}{l}\text { (Stuckler et al., 2009; Jefferis et al., } \\
\text { 2011; Norström and Grönqvist, } \\
\text { 2015, Pohlan, 2019). }\end{array}$ & $\begin{array}{l}\text { Unemployment can lead to harmful } \\
\text { diseases, such as, suicide and depression } \\
\text { in the fields of epidemiology, } \\
\text { psychology and sociology. }\end{array}$ \\
\hline Well-being & \multirow[b]{2}{*}{$\begin{array}{l}\text { (Paul and Moser, 2009; Strandh } \\
\text { et al., 2013; Knabe et al., 2016). } \\
\text { (Bolton and Oatley, 1987; } \\
\text { Wadsworth et al., 1999; Broom } \\
\text { et al., 2006; Jefferis et al., 2011). } \\
\text { (Clark and Oswald, 1994; Lucas } \\
\text { et al., 2004; Paul and Moser, 2009; } \\
\text { Wulfgramm, 2011a, 2011b; Young, } \\
\text { 2012). }\end{array}$} & \multirow[b]{2}{*}{$\begin{array}{l}\text { Unemployment affects the well-being } \\
\text { of the unemployed in different ways } \\
\text { and depends on context and identity, } \\
\text { on depression and shame and on life } \\
\text { satisfaction. In general, unemployment } \\
\text { reduces the welfare of the unemployed. }\end{array}$} \\
\hline $\begin{array}{l}\text { - Context and identity } \\
\text { - Depression and shame } \\
\text { - Life satisfaction }\end{array}$ & & \\
\hline Social exclusion & (Jahoda et al., 1971; Pohlan, 2019). & $\begin{array}{l}\text { Unemployment excludes } \\
\text { the unemployed from community life, } \\
\text { which worsens their social life } \\
\text { and gives them a predominantly feeling } \\
\text { of resignation and apathy. }\end{array}$ \\
\hline \multicolumn{3}{|c|}{ ALMP effect on the subjective well-being } \\
\hline$A L M P$ & $\begin{array}{l}\text { (Donovan et al., 1986; Korpi, 1997; } \\
\text { Creed et al., 1999; Strandh, 2001; } \\
\text { Andersen, 2008; Wulfgramm, 2011a, } \\
\text { 2011b; Krause, 2013; Sage, 2015a,b; } \\
\text { Carter and Whitworth, 2017; Sage, } \\
\text { 2018; Rose, 2019; Puig-Barrachina } \\
\text { et al., 2020). } \\
\text { (Creed, 1998; Breidahl and } \\
\text { Clements, 2010; Reine et al., 2011; } \\
\text { Wanberg, 2012). }\end{array}$ & $\begin{array}{l}\text { ALMPs can have positive effects } \\
\text { on the subjective well-being. }\end{array}$ \\
\hline At the national level & $\begin{array}{l}\text { Vinokur et al. (2000) and Vuori et al. } \\
\text { (2002) in USA and Finland, Creed } \\
\text { et al. (2001) in Australia, Behle (2005) } \\
\text { and Wulfgramm, (2011a, 2011b) } \\
\text { in Germany, Hagquist and Starrin } \\
\text { (1996), Korpi (1997) and Strandh } \\
\text { (2001) in Sweden, Anderson (2008), } \\
\text { Bonin and Rinne (2014) in Serbia. }\end{array}$ & \\
\hline \multicolumn{3}{|l|}{ Types of ALMP } \\
\hline - Work-place & $\begin{array}{l}\text { (Donovan et al., 1986; Creed et al., } \\
\text { 1999; Strandh 2001; Anderson, } \\
\text { 2008; Sage, 2015a,b; Hetschko et al., } \\
\text { 2016). } \\
\text { (Creed et al., 2001; Strandh, 2001; } \\
\text { Anderson, 2008; Wulfgramm, } \\
\text { 2011a, 2011b, Puig-Barrachina et al., } \\
\text { 2020). } \\
\text { (Sage, 2015b, Carter and Whitworth, } \\
\text { 2017). }\end{array}$ & $\begin{array}{l}\text { Training programs have shown positive } \\
\text { impact on the subjective well-being. }\end{array}$ \\
\hline - Work-oriented & (Rose, 2019). & $\begin{array}{l}\text { Work-oriented ALMPs are associated } \\
\text { with higher subjective well-being }\end{array}$ \\
\hline Employment assistance & $\begin{array}{l}\text { (Caliendo, 2009; Caliendo and } \\
\text { Kritikos, 2010; Crost, 2016; } \\
\text { Sage, 2018; Ivanov et al., 2020; } \\
\text { Puig-Barrachina et al., 2020). }\end{array}$ & $\begin{array}{l}\text { relative to unemployment compared } \\
\text { to employment-assisted program. } \\
\text { Employment assistance have proven } \\
\text { to have positive impact on the subjective } \\
\text { well-being. }\end{array}$ \\
\hline $\begin{array}{l}\text { Wage subsidies } \\
\text { and subsidized } \\
\text { self-employment }\end{array}$ & $\begin{array}{l}\text { (Caliendo, 2009; Caliendo and } \\
\text { Kritikos, 2010; Korpi, 1997; } \\
\text { Rose, 2019; Ivanov et al., 2020; } \\
\text { Puig-Barrachina et al., 2020). }\end{array}$ & $\begin{array}{l}\text { Wage subsidies and subsidized } \\
\text { self-employment appear to have } \\
\text { a more modest effect on the subjective } \\
\text { well-being. }\end{array}$ \\
\hline
\end{tabular}

Source: Authors' elaboration based on literature review. 
Their results are consistent with those of (Strandh, 2001; Sage, 2015a). A recent study on the UK context welfare state was conducted by Sage (2018), which showed that ALMPs can have the capacity to improve welfare losses experienced during a period of unemployment. He also argued that the different types of ALMP interact with the unemployed, e.g. employment assistance programs have proven to have positive welfare effects as opposed to work participation programs such as the Mandatory Work Activity. In addition, Rose (2019) used a new panel survey, the IZA evaluation database in Germany, and applied a propensity score matching approach with differences in differences. The author concluded that ALMPs have a positive effect on the subjective well-being. Thus, the types of ALMPs that appear to have a more modest effect on the well-being are wage subsidies and subsidized self-employment. The training programs are found to have a small impact on the well-being of the unemployed. Their result for regional differences is mixed and the impact of ALMPs on the well-being of the female is not significant. However, other studies are shown to have no evidence of the effects of ALMPs on the well-being, physical health and social capital of participants (Creed, 1998; Breidahl and Clements, 2010; Reine, Novo and Hammarström, 2011; Wanberg, 2012).

Therefore, the aim of our paper is to test the effectiveness of ALMPs participants on the subjective well-being of the unemployed and whether some type of ALMPs are more effective i.e. that they could have differential effects on the subjective well-being.

\section{Data and Methodology}

\subsection{Data}

The macro data analyzed below come from the OECD database and World Happiness Report covering the period 2005 - 2016. Our data were available for 29 OECD countries. Four groups or social models covering four geographical areas stand out within the OECD (Bouis and Renne, 2006; Rovelli and Bruno, 2008). An Anglo-Saxon group (Canada, Ireland, United Kingdom, United States, Australia and New-Zealand), a Continental group (Austria, Belgium, France, Luxembourg, Germany and the Netherlands), a Scandinavian group (Denmark, Finland, Norway and Sweden) a Mediterranean group (Italy, Portugal, Spain and Greece) and other group (Czech republic, Estonia, Israel, Poland, Slovenia, Switzerland, Latvia, Lithuania, and Slovakia). The dependent variable used is subjective well-being or Happiness score which also referred to as Cantril life ladder. Our main variables of interest which constitute a labor market status are 
the participants of ALMP, participants of each type of ALMP, participants of Passive Labor Market Policies (PLMP) and the unemployment rate. In addition, we employed control variables, such as GDP per capita and social expenditure (\% GDP). The definition of the variables and their sources are presented in Table 2. The descriptive statistics and correlation matrix are presented in Table 3 and Table 4 (in the Appendix) respectively. The relationship between the variables indicates that the subjective well-being appears to be positively correlated with the total ALMP, training, employment incentives, supported employment and rehabilitation, start-up incentives, gross domestic product, social expenditure, Anglo-Saxon, Scandinavian and Continental group. On the other hand, the subjective well-being is negatively correlated with unemployment rate, direct job creation, crisis, Mediterranean and the Other group.

Table 2

Definition and Source of Variables

\begin{tabular}{|c|c|c|}
\hline Variables & Definition & Sources \\
\hline Subjective well-being & $\begin{array}{l}\text { It is the national average response to the question of life } \\
\text { evaluations. The question is "Please imagine a ladder } \\
\text { with steps numbered from } 0 \text { at the bottom to } 10 \text { at the top. } \\
\text { The top of the ladder represents the best possible life } \\
\text { for you and the bottom of the ladder represents the worst } \\
\text { possible life for you. }\end{array}$ & $\begin{array}{l}\text { World Happiness } \\
\text { Report (2017) }\end{array}$ \\
\hline $\begin{array}{l}\text { Unemployment rate } \\
(\% \text { of the labor force) }\end{array}$ & The unemployed persons aged $15-64$. & OECD (2017) \\
\hline $\begin{array}{l}\text { Participants stocks } \\
\text { on ALMP (\% labor force) }\end{array}$ & Participant stocks on ALMP (\% labor force). & OECD (2017) \\
\hline $\begin{array}{l}\text { Participants of each type } \\
\text { of ALMP (\% labor force) }\end{array}$ & $\begin{array}{l}\text { Stocks of ALMP participants by main category } \\
\text { (\% labor force). }\end{array}$ & OECD (2017) \\
\hline $\begin{array}{l}\text { Participants stocks } \\
\text { of PLMP (\% labor force) }\end{array}$ & $\begin{array}{l}\text { Workers who, working on their own account or with one } \\
\text { or a few partners or in cooperative, hold the type of jobs } \\
\text { defined as a "self-employment jobs". }\end{array}$ & OECD (2017) \\
\hline $\begin{array}{l}\text { GDP per capita } \\
\text { (current USD) }\end{array}$ & $\begin{array}{l}\text { Gross Domestic Product divided by midyear population. } \\
\text { Data are in current US dollars. }\end{array}$ & OECD (2017) \\
\hline $\begin{array}{l}\text { Social expenditure } \\
(\% \text { of GDP) }\end{array}$ & $\begin{array}{l}\text { Comprises cash benefits, direct in-kind provision of goods } \\
\text { and services, and tax breaks with social purposes. Benefits } \\
\text { may be targeted at low-income households, the elderly, } \\
\text { disabled, sick, unemployed, or young persons. }\end{array}$ & OECD (2017) \\
\hline Period Crisis & $\begin{array}{l}\text { Dummy variable taking the value of one in } 2008 \text { and } 2009 \\
\text { years and zero otherwise. }\end{array}$ & \\
\hline $\begin{array}{l}\text { Geographic (binary) } \\
\text { variables }\end{array}$ & $\begin{array}{l}\text { Anglo-Saxon group (Canada, Ireland, United Kingdom, } \\
\text { United States, Australia and New-Zealand), Continental } \\
\text { group (Austria, Belgium, France, Luxembourg, Germany } \\
\text { and the Netherlands), Scandinavian group (Denmark, } \\
\text { Finland, Norway and Sweden), Mediterranean group } \\
\text { (Italy, Portugal, Spain and Greece) and Other group } \\
\text { (Czech republic, Estonia, Israel, Poland, Slovenia, } \\
\text { Switzerland, Latvia, Lithuania and Slovakia). }\end{array}$ & \\
\hline
\end{tabular}

Source: Own. 
T a ble 3

\section{Descriptive Statistics}

\begin{tabular}{|l|c|c|c|c|r|}
\hline Variables & Obs. & Mean & Std. dev. & Min & Max \\
\hline Subjective well-being & 284 & 6.685 & 0.799 & 4.66 & 8.01 \\
Participants stocks on ALMP & 316 & 3.516 & 2.616 & 0.15 & 19.43 \\
Training & 309 & 1.162 & 0.934 & 0 & 4.42 \\
Employment incentives & 290 & 1.457 & 2.135 & 0 & 16.48 \\
Supported employment and rehabilitation & 275 & 0.484 & 0.610 & 0 & 3.65 \\
Direct job creation & 304 & 0.376 & 0.505 & 0 & 4.02 \\
Start-up incentives & 292 & 0.191 & 0.337 & 0 & 1.94 \\
Unemployment & 348 & 8.220 & 4.320 & 2.49 & 27.47 \\
Participants stocks on PLMP & 319 & 5.861 & 4.083 & 1.12 & 20.1 \\
Ln GDP & 348 & 10.478 & 0.564 & 9.20 & 11.62 \\
Social expenditure & 348 & 21.353 & 4.737 & 11.07 & 32.21 \\
Crisis & 348 & 0.166 & 0.373 & 0 & 1 \\
Anglo-Saxon & 348 & 0.206 & 0.405 & 0 & 1 \\
Continental & 348 & 0.206 & 0.405 & 0 & 1 \\
Scandinavian & 348 & 0.137 & 0.345 & 0 & 1 \\
Mediterranean & 348 & 0.172 & 0.378 & 0 & 1 \\
Other group & 348 & 0.275 & 0.447 & 0 & 1 \\
\hline
\end{tabular}

Source: Own calculations, based on data from the World Happiness Report and the OECD.

\subsection{Methodology}

We estimate a dynamic panel data models via the General Method of Moments (GMM) system estimator which first proposed by Arrelano and Bond (1991) and further developed by Arellano and Bover (1995) and Blundell and Bond (1998). Therefore, we proposed our model as follows:

$$
\begin{gathered}
S W B=\alpha S W B_{i t-1}+\beta_{1} A L M P_{i t}+\beta_{2} P L M P_{i t}+\beta_{3} U N_{i t}+\beta_{4} G D P_{i t}+ \\
+\beta_{5} S E_{i t}+\mu_{i}+v_{t}+\varepsilon_{i t}
\end{gathered}
$$

where

$S W B_{i t} \quad$ - denotes the subjective well-being,

$S W B_{i t} \quad$ - the lagged dependent variable,

$P A M T_{i t}$ - indicates the Active Labor Market Policies,

$P L M P_{i t}$ - indicates the Passive Labor Market Policies,

$U N_{i t}$ - denotes the unemployment rate,

$G D P_{i t}$ - denotes the gross domestic product,

$S E_{i t} \quad$ - indicates the social expenditure,

$\mu_{i} \quad$ - the specific individual effect,

$v_{t} \quad-$ the specific effect of time,

$\varepsilon_{i t} \quad-$ attests the error term ( $i$ is the individual index and $t$ the time index).

We have used different estimation techniques to estimate the regression coefficients $\alpha$ and $\beta$ to identify the effect of ALMP and unemployment on the subjective well-being. We note that the estimation of a dynamic model with 
ordinary least squares (OLS) and fixed effects (FE) estimates remains limited (Aisen and Veiga, 2013) because it allows us to produce biased estimates in presence of delayed dependent variables as regressors as well as we have done for the verification. Then, we have used the estimate with GMM dynamic system to solve the simultaneity bias problems of inverse causality and omitted variables. Moreover, it allows us to control the individual specific effects $\mu_{i}$ and the effects of time $v_{t}$ to overcome the endogeneity bias. For these reasons, we used a two-step dynamic panel estimation implemented via the general method of moments (GMM) system estimator which was developed by Arellano and Bover (1995) and Blundell and Bond (1998). We used the xtabond2 command (Roodman, 2009) to run GMM System estimation in Stata. In addition, we checked the estimation by using three tests for empirical models. The test of Blundell and Bond (1998) is first applied to analyze the existence of second-order autocorrelation in the first differential errors. The Sargan test is considered as an orthogonality test between regressors and instruments in the estimation of GMM. The "Durbin-Wu-Hausman test" aims at controlling endogeneity.

\section{Results and Discussions}

Using different estimates (OLS, FE, GMM system), two models were implemented. The first is to identify the causal effect of ALMPs, PLMPs, and unemployment on wellbeing, while the second consists in dividing the ALMPs into five types to detect the ALMP that appear to have the best results on well-being. The objective of these two models is to test whether the effect of ALMPs on SWB varies between types of ALMPs.

Table 5 shows the regression results for the determinants of subjective wellbeing. The regression of OLS, the fixed effect and GMM system practically show the same influences of the exogenous variables, both in significance and direction. The result given in model (1) with system GMM estimation indicates that unemployment negatively affects the subjective well-being of the unemployed at 5\% level. ${ }^{4}$ This can be explained by Jahoda's (1982) theory that the unemployed are essentially deprived of five psychosocial functions of work (imposition of a temporal structure, social contacts, participation in a collective goal, status and identity and regular activity required) which diminishes their subjective well-being.

\footnotetext{
${ }^{4}$ Our results are consistent with the findings of (Donovan et al., 1986; Clark and Oswald, 1994; Korpi, 1997; Murphy and Athanasou, 1999; Strandh, 2001; Lucas et al., 2004; Carroll, 2007; Andersen, 2008; 2009; Clark, Knabe and Rätzel, 2010; Wulfgramm, 2011a; 2011b; Pholan, 2019).
} 
T a ble 5

Baseline Results

\begin{tabular}{|c|c|c|c|c|c|c|}
\hline \multirow{2}{*}{ Variables } & \multicolumn{2}{|c|}{ OLS } & \multicolumn{2}{|c|}{ FE } & \multicolumn{2}{|c|}{ SGMM } \\
\hline & Model (1) & Model (2) & Model (1) & Model (2) & Model (1) & Model (2) \\
\hline$S W B_{t-1}$ & & & & & $\begin{array}{l}0.817 \text { *** } \\
(0.111)\end{array}$ & $\begin{array}{l}0.841 \text { *** } \\
(0.102)\end{array}$ \\
\hline$A L M P$ & $\begin{array}{l}0.010 * * \\
(0.003)\end{array}$ & & $\begin{array}{l}0.012^{\text {*** }} \\
(0.001)\end{array}$ & & $\begin{array}{l}0.031 * * \\
(0.014)\end{array}$ & \\
\hline$T R A$ & & $\begin{array}{l}0.084^{* *} \\
(0.021)\end{array}$ & & $\begin{array}{l}0.111^{* *} \\
(0.031)\end{array}$ & & $\begin{array}{l}0.129 * * \\
(0.054)\end{array}$ \\
\hline$E I$ & & $\begin{array}{l}0.216^{* * * *} \\
(0.051)\end{array}$ & & $\begin{array}{l}0.221 * * * \\
(0.034)\end{array}$ & & $\begin{array}{l}0.220 * * * \\
(0.021)\end{array}$ \\
\hline$\overline{S E R}$ & & $\begin{array}{c}0.026 \\
(0.038)\end{array}$ & & $\begin{array}{c}0.009 \\
(0.044)\end{array}$ & & $\begin{array}{c}0.040 \\
(0.049)\end{array}$ \\
\hline DJC & & $\begin{array}{r}-0.010^{*} \\
(0.093)\end{array}$ & & $\begin{array}{r}-0.059^{*} \\
(0.024)\end{array}$ & & $\begin{array}{r}-0.035^{*} \\
(0.019)\end{array}$ \\
\hline$S I$ & & $\begin{array}{l}0.286^{* * * *} \\
(0.017)\end{array}$ & & $\begin{array}{l}0.274 * * * \\
(0.059)\end{array}$ & & $\begin{array}{l}0.240 * * * \\
(0.079)\end{array}$ \\
\hline$P L M P$ & $\begin{array}{l}0.005 * * \\
(0.001) \\
\end{array}$ & $\begin{array}{l}0.003 * * \\
(0.000)\end{array}$ & $\begin{array}{l}0.001^{\text {*** }} \\
(0.003)\end{array}$ & $\begin{array}{l}0.002^{* *} \\
(0.004)\end{array}$ & $\begin{array}{l}0.016^{* * *} \\
(0.009) \\
\end{array}$ & $\begin{array}{l}0.022^{* *} \\
(0.011)\end{array}$ \\
\hline$U N$ & $\begin{array}{l}-0.040 * * * \\
(0.007)\end{array}$ & $\begin{array}{l}-0.013 * * * \\
(0.012)\end{array}$ & $\begin{array}{l}-0.042^{* * * *} \\
(0.008)\end{array}$ & $\begin{array}{c}-0.036^{* * * *} \\
(0.011)\end{array}$ & $\begin{array}{l}-0.044 * * \\
(0.009)\end{array}$ & $\begin{array}{c}-0.023 * * \\
(0.010)\end{array}$ \\
\hline$G D P$ & $\begin{array}{l}0.898 * * * \\
(0.130)\end{array}$ & $\begin{array}{l}1.324 * * * \\
(0.085)\end{array}$ & $\begin{array}{l}0.581^{* * *} \\
(0.255)\end{array}$ & $\begin{array}{l}1.078 * * * \\
(0.380)\end{array}$ & $\begin{array}{l}0.388^{* * * *} \\
(0.111)\end{array}$ & $\begin{array}{l}0.346^{* * * *} \\
(0.159)\end{array}$ \\
\hline$S E$ & $\begin{array}{c}0.009 \\
(0.010)\end{array}$ & $\begin{array}{c}-0.004 \\
(0.070)\end{array}$ & $\begin{array}{c}0.012 \\
(0.010)\end{array}$ & $\begin{array}{c}0.020 \\
(0.012)\end{array}$ & $\begin{array}{c}0.009 \\
(0.011)\end{array}$ & $\begin{array}{c}-0.018 \\
(0.006)\end{array}$ \\
\hline Constant & $\begin{array}{r}-2.575^{*} \\
(1.372)\end{array}$ & $\begin{array}{l}-6.847 * * * \\
(0.881)\end{array}$ & $\begin{array}{l}2.562^{* * *} \\
(1.285)\end{array}$ & $\begin{array}{c}-4.725 \\
(4.078)\end{array}$ & $\begin{array}{l}1.047 * * \\
(1.167)\end{array}$ & $\begin{array}{c}-2.876^{* * *} \\
(1.374)\end{array}$ \\
\hline $\begin{array}{l}\text { Observations } \\
\text { R-squared } \\
\text { Number of instruments } \\
\text { DWH test: } p \text { value } \\
\text { Sargan test: } p \text { value } \\
\text { AR (1): } p \text { value } \\
\text { AR (2): } p \text { value }\end{array}$ & $\begin{array}{l}253 \\
0.73\end{array}$ & $\begin{array}{l}184 \\
0.68\end{array}$ & $\begin{array}{l}253 \\
0.71\end{array}$ & $\begin{array}{l}184 \\
0.69\end{array}$ & $\begin{array}{c}189 \\
\\
61 \\
0.005 \\
0.210 \\
0.000 \\
0.992\end{array}$ & $\begin{array}{c}144 \\
109 \\
0.006 \\
0.286 \\
0.000 \\
0.505\end{array}$ \\
\hline
\end{tabular}

Note: $O L S$ ordinary least squares, FE Fixed-effects model and SGMM indicate the system generalized method of moments. Standard-error is in parentheses. *,** and *** denote significance at the 10, 5 and $1 \%$ level, respectively. SGMM regression uses robust standard errors clustered by country.

Source: Authors' estimation (STATA).

This theory was confirmed by (Van der Meer and Tolsma, 2014) who affirmed that getting a job is an important societal norm and allow people to earn income that gives them comfort, stimulation and a status thus the gain in subjective wellbeing. In fact, the relationship between subjective well-being and unemployment is intrinsically linked to the extent to which the unemployed are governed in a broad sense and in relation to specific institutionalized practices. According to (Pultz and Teasdale, 2017), the relationship between unemployment and wellbeing is largely influenced by neoliberal policies (such as, shame, self-blame, work ethic and flexibility) and the level of well-being improves when people are not considered unemployed. The results also indicate that both participants of ALMP and PLMP enhance people's sense of subjective well-being. These variables are 
significantly and negatively linked to the subjective well-being at 5\% level, as expected. These results strengthen the argument that in order to improve the subjective well-being of the unemployed, measures should focus on ALMPs that offer psychological benefits to the unemployed (Sage, 2015a). This implies that participation in ALMPs and PLMP influences the subjective well-being of the unemployed. Therefore, our empirical finding is confirmed with that of (Wulfgramm, 2014). In fact, the interest of ALMP participation is to mitigate the negative effects of unemployment (Sage, 2015a), however these employment policy measures certainly have a sociological and psychological concept about the unemployed. According to Dolan, Layard and Metcalfe (2011), ALMPs as statefinanced employment guarantees constitute an incentive to the subjective wellbeing of the unemployed. In addition, ALMPs constitute a form of intermediate status in the labor market (Coutts, Stuckler and Cann, 2014) by offering participants organized activities and a daily routine. Interventions that improve the well-being of the unemployed should be adapted and implemented in OECD countries (Sage, 2015a,b). Moreover, ALMP participants respond to the needs of development recognized by (Jahoda, Lazarsfeld and Zeisel, 1971; Jahoda, 1982). Therefore, ALMPs appear to be effective interventions in labor market to promote the psychosocial resilience of unemployed people.

Furthermore, the results suggest that participants on ALMPs are more pronounced among individuals who participants on PLMPs. The same result is confirmed with Wulfgramm (2014) who suggests that encouraging unemployed people to participate on ALMPs stimulates their well-being rather than participating on PLMPs whose only function is to reduce the negative consequences of unemployment through unemployment insurance and benefits. According to this author, ALMPs and PLMPs play a significant role in determining the well-being of the unemployed, as unemployed people in a country receiving unemployment benefits are at risk of less severe stigmatization and thus loss of income and well-being compared to those living in an extremely generous country.

To show the effectiveness of ALMPs in improving well-being, it is obvious to explore which types of ALMP work best and provide more effective feelings of well-being. It is the object of the second model. Indeed, more the different types of ALMPs have a multifunctionality, the greater the impact on well-being would be (Wulfgramm, 2011a; 2011b; Rose, 2019). Employment incentives and start-up incentives programs are positively and significantly correlated with the well-being at $1 \%$ level. In particular, these two measures of ALMPs have proved to be the most effective in improving the well-being of the unemployed. This implies that these programs meet essential objectives (characteristics) similar to those of employment, which favors their impact on well-being. Our result corroborates 
that of (Caliendo, 2009; Caliendo and Kritikos, 2010; Puig-Barrachina et al., 2020). On the one hand, start-up incentives encourage the unemployed and other target groups by giving them a start-up grant to start their businesses and become independent entrepreneurs. On the other hand, wage subsidies (employment incentives) aim at integrating the unemployed into the labor market by granting them a wage subsidy and by in demanding them for their low productivity (Wolff and Stephan, 2013; Sahnoun and Abdennadher, 2018b). For instance, the wage subsidy "the income tax credit" in the United States and the "employment premium" in France which provide additional benefits to whose income are below sociocultural subsistence income. As a result, these benefits provide a sense of well-being to those participating in these programs. On the other hand, these programs can lead to stigmatization of the status of participants, which increases as they receive social well-being. Generally, these measures of ALMP (employment incentives and start-up incentives) contribute to the creation of comfort through financing or income and an increase in stimulation through work (physical or mental effort).

The results also reveal that training program generally boost subjective wellbeing among unemployed. Training programs show a lower impact but significant and positive with subjective well-being at the 5\% level. ${ }^{5}$ Indeed, these programs include (classroom training, vocational training, job training and work experience, etc.) are essential to skills development and can improve human capital (Kluve et al., 2007; Caliendo and Schmidl, 2016). Moreover, training is oriented towards human capital, it is fundamental that this program is a key determinant of success in the labor market in terms of combating unemployment and the acquisition of real skills (Sperreboom and Staneva, 2014). This outcome prove that training programs affect the well-being of the unemployed by rewarding working for their own lives, providing support from society and respecting certain labor standards (Anderson, 2008). Also, these policies become more beneficial when participants see them as opportunities to increase their ability to secure future employment i.e. alleviate the burden of unemployment of participants. However, our results contradict those of (Wulfgramm, 2011a; 2011b) who argued that participation in training reduces the well-being of the unemployed if these programs are considered degrading.

On the other hand, the participation in direct job creation programs shows a negative and significant effect at 5\% level on the subjective well-being of the unemployed. Our result takes against the dominant paradigm in which participation

\footnotetext{
${ }^{5}$ Our results are consistent with those of (Donovan et al., 1986; Creed et al., 1999; Strandh 2001; Anderson, 2008; Sage, 2015a; 2015b; Hetschko, Schöb and Wolf, 2016; Puig-Barrachina et al., 2020).
} 
in the direct job creation program (subsidized jobs, direct job creation plans, subsidized contracts) reduces ceteris paribus subjective well-being losses for the unemployed. ${ }^{6}$ Why? Because, from the cost-benefit calculation of this program, it appears that the gain resulting from exiting unemployment is greater than unemployment insurance. However, this program risks decreasing the search intensity (effort), thus restricting the employment possibilities of the beneficiaries and creating negative locking-in effects on the search behavior of the individual during the period of participation in program.

Our results do not contain evidence for supported employment and rehabilitation. This is most likely due to the fact that being out of the labor force is involuntary, that the individual is not working for a reason that is not their own choice.

To sum up, somehow employment incentives, start-up and training programs has a significantly positive effect on the subjective well-being compared to direct job creation and supported employment and rehabilitation.

For the others control variables, our findings suggest that GDP is positively and significantly correlated with the subjective well-being. ${ }^{7}$ This suggests that people are happier if labor market conditions are better. According to Oswald (1997), economic things matter only in so far as they make people "happier". Finally, social expenditure is not found affected the subjective well-being of unemployed. This implies that an increase of government spending does not raise the well-being which has been confirmed by (Kacapyr, 2008; Ram, 2009).

\section{Robustness Check}

To check the robustness of our results, we use three other control variables; a geographic affiliation variable that indicates the differences between groups of countries, a crisis dummy to control for the effect of the 2008 - 2009 financial crisis and an interaction between ALMP and crisis. Table 6 presents the results of this robustness test. The effect of the 2008 global financial crisis on the subjective well-being of the unemployed was found to be negative, but not significant. Nonetheless, we note that in times of crisis, the effectiveness of ALMPs is positively correlated with subjective well-being, which suggests that these policies are more effective in recessive markets, as indicated by the interaction term "ALMP*CRISIS".

\footnotetext{
${ }^{6}$ (Wulfgramm, 2011a; 2011b; Crost, 2016; Knabe et al., 2016, Ivanov, Pfeiffer and Pohlan, 2020).

${ }^{7}$ Several studies support these results (Deaton, 2008; Stevenson and Wolfers, 2008; Easterlin, Angelescu and Zweig, 2011; Howarth and Kennedy, 2016).
} 
T a b le 6

Additional Robustness Tests

\begin{tabular}{|c|c|c|c|c|c|c|}
\hline \multirow{2}{*}{ Variables } & \multicolumn{2}{|c|}{ OLS } & \multicolumn{2}{|c|}{ FE } & \multicolumn{2}{|c|}{ SGMM } \\
\hline & Model (1) & Model (2) & Model (1) & Model (2) & Model (1) & Model (2) \\
\hline$S W B_{t-1}$ & & & & & $\begin{array}{l}0.834 * * * \\
(0.057)\end{array}$ & $\begin{array}{l}0.841 * * * \\
(0.102)\end{array}$ \\
\hline$A L M P$ & $\begin{array}{l}0.040 * * \\
(0.007)\end{array}$ & & $\begin{array}{l}0.042 * * \\
(0.008)\end{array}$ & & $\begin{array}{l}0.032 * * \\
(0.007)\end{array}$ & \\
\hline$T R A$ & & $\begin{array}{l}0.084 * * \\
(0.021)\end{array}$ & & $\begin{array}{l}0.111 * * \\
(0.031)\end{array}$ & & $\begin{array}{l}0.129 * * \\
(0.054)\end{array}$ \\
\hline$E I$ & & $\begin{array}{l}0.216^{* * * *} \\
(0.051)\end{array}$ & & $\begin{array}{l}0.221 * * * \\
(0.034)\end{array}$ & & $\begin{array}{l}0.220 * * * \\
(0.021)\end{array}$ \\
\hline SER & & $\begin{array}{c}0.026 \\
(0.038)\end{array}$ & & $\begin{array}{c}0.009 \\
(0.044)\end{array}$ & & $\begin{array}{l}0.040 \\
(0.049)\end{array}$ \\
\hline DJC & & $\begin{array}{r}-0.010^{*} \\
(0.093)\end{array}$ & & $\begin{array}{r}-0.059^{*} \\
(0.024)\end{array}$ & & $\begin{array}{r}-0.035^{*} \\
(0.019)\end{array}$ \\
\hline$S I$ & & $\begin{array}{l}0.286 * * * \\
(0.017)\end{array}$ & & $\begin{array}{l}0.274 * * * \\
(0.059)\end{array}$ & & $\begin{array}{l}0.240 * * * \\
(0.079)\end{array}$ \\
\hline PLMP & $\begin{array}{l}0.056^{* *} \\
(0.018)\end{array}$ & $\begin{array}{l}0.003^{* *} \\
(0.000)\end{array}$ & $\begin{array}{l}0.030 * * \\
(0.010)\end{array}$ & $\begin{array}{l}0.002 * * \\
(0.004)\end{array}$ & $\begin{array}{l}0.036^{* * *} \\
(0.019)\end{array}$ & $\begin{array}{l}0.022^{* *} \\
(0.011)\end{array}$ \\
\hline$U N$ & $\begin{array}{c}-0.066^{* * * *} \\
(0.037)\end{array}$ & $\begin{array}{c}-0.013 * * * \\
(0.012)\end{array}$ & $\begin{array}{c}-0.040 * * * \\
(0.007)\end{array}$ & $\begin{array}{c}-0.036^{* * * *} \\
(0.011)\end{array}$ & $\begin{array}{c}-0.054 * * \\
(0.027)\end{array}$ & $\begin{array}{c}-0.023^{* *} * \\
(0.010)\end{array}$ \\
\hline$G D P$ & $\begin{array}{l}0.929 * * * \\
(0.242)\end{array}$ & $\begin{array}{l}1.324 * * * \\
(0.085)\end{array}$ & $\begin{array}{l}0.521 * * \\
(0.217)\end{array}$ & $\begin{array}{l}1.078 * * * \\
(0.380)\end{array}$ & $\begin{array}{l}0.286^{* * * *} \\
(0.117)\end{array}$ & $\begin{array}{l}0.346^{* * * *} \\
(0.159)\end{array}$ \\
\hline$S E$ & $\begin{array}{c}0.075 \\
(0.805)\end{array}$ & $\begin{array}{c}-0.004 \\
(0.070)\end{array}$ & $\begin{array}{c}0.061 \\
(0.431)\end{array}$ & $\begin{array}{c}0.020 \\
(0.012)\end{array}$ & $\begin{array}{c}0.034 \\
(0.185)\end{array}$ & $\begin{array}{c}-0.018 \\
(0.006)\end{array}$ \\
\hline Crisis & $\begin{array}{c}-0.593 \\
(0.537)\end{array}$ & & $\begin{array}{c}-0.910 \\
(0.575)\end{array}$ & & $\begin{array}{c}-0.673 \\
(0.608)\end{array}$ & \\
\hline$A L M P^{*}$ Crisis & $\begin{array}{l}0.030 * * \\
(0.014)\end{array}$ & & $\begin{array}{l}0.037 * * \\
(0.024)\end{array}$ & & $\begin{array}{l}0.034 * * \\
(0.010)\end{array}$ & \\
\hline Anglo-Saxon & $\begin{array}{l}2.255 \\
(2.628)\end{array}$ & & $\begin{array}{c}2.470 \\
(2.712)\end{array}$ & & $\begin{array}{c}-1.659 \\
(2.389)\end{array}$ & \\
\hline Continental & $\begin{array}{l}4.216 \\
(2.577)\end{array}$ & & $\begin{array}{c}2.130 \\
(1.782)\end{array}$ & & $\begin{array}{l}1.032 * * \\
(0.457)\end{array}$ & \\
\hline Scandinavian & $\begin{array}{c}3.271 \\
(2.822)\end{array}$ & & $\begin{array}{c}2.586 \\
(1.797)\end{array}$ & & $\begin{array}{l}1.391 \text { *** } \\
(0.507)\end{array}$ & \\
\hline Mediterranean & $\begin{array}{c}-3.030 \\
(2.520)\end{array}$ & & $\begin{array}{c}-1.036 \\
(1.948)\end{array}$ & & $\begin{array}{c}-2.393 \\
(2.821)\end{array}$ & \\
\hline Other group & $\begin{array}{c}3.558 \\
(3.697)\end{array}$ & & $\begin{array}{c}-2.318 \\
(3.007)\end{array}$ & & $\begin{array}{c}-1.659 \\
(2.389)\end{array}$ & \\
\hline Constant & $\begin{array}{c}-3.239 * * * \\
(1.170)\end{array}$ & $\begin{array}{l}-6.847 * * * \\
(0.881)\end{array}$ & $\begin{array}{l}2.151 * * * \\
(0.551) \\
\end{array}$ & $\begin{array}{c}-4.725 \\
(4.078)\end{array}$ & $\begin{array}{l}1.187 * * * \\
(0.283)\end{array}$ & $\begin{array}{c}-2.876^{* *} \\
(1.374) \\
\end{array}$ \\
\hline $\begin{array}{l}\text { Observations } \\
\text { R-squared } \\
\text { Number of instruments } \\
\text { DWH test: } p \text { value } \\
\text { Sargan test: } p \text { value } \\
\text { AR (1): } p \text { value } \\
\text { AR (2): } p \text { value }\end{array}$ & $\begin{array}{l}253 \\
0.77\end{array}$ & $\begin{array}{c}184 \\
0.68\end{array}$ & $\begin{array}{l}253 \\
0.78\end{array}$ & $\begin{array}{l}184 \\
0.69\end{array}$ & $\begin{array}{c}189 \\
70 \\
0.003 \\
0.213 \\
0.000 \\
0.888 \\
\end{array}$ & $\begin{array}{c}144 \\
109 \\
0.006 \\
0.286 \\
0.000 \\
0.505 \\
\end{array}$ \\
\hline
\end{tabular}

Note: $O L S$ ordinary least squares, FE Fixed-effects model and SGMM indicate the system generalized method of moments. Standard-error is in parentheses. $*$, ** and *** denote significance at the 10,5 and $1 \%$ level, respectively. SGMM regression uses robust standard errors clustered by country.

Source: Authors' estimation (STATA).

This result indicates that active labor market policies have proven to be effective tools to reduce the unemployment rate which would take the form of gains 
in terms of well-being ${ }^{8}$ by strengthening resilience to adversity (in this case, the 2008 economic crisis) (Hur, 2019; Morgan and O'Connor, 2019). In this context, a recent empirical work (Card, Kluve and Weber, 2018) confirms that the effectiveness of ALMPs depend on cyclical factors such as the position of the economy in the cycle, which suggests that these policies are more effective in recessive markets in reducing the unemployment rate and therefore in the gain of the well-being. The effect of the (binary) variables of geographical affiliation (positive and significant) on the subjective well-being cannot be separated from the reference to a social protection system compatible with high "active" expenditure and low unemployment. The example of the Scandinavian and Continental countries is very instructive in this regard. ${ }^{9}$

\section{Conclusion}

Unemployment is an environment generally seen as involving various forms of loss. Previous research has shown that unemployment has a strong negative effect on health, well-being and social exclusion (Strandh et al., 2013; Knabe, Schöb and Weimann, 2016; Pohlan, 2019; Puig-Barrachina et al., 2020). In particular, unemployment harms well-being because of its negative effects on income, making people less financially secure and less able to meet their material needs and wants. Moreover, unemployment is also considered to be harmful because of its detrimental psychological effects, regardless of its material impacts (Sage, 2018).

First, we focused on the effects of ALMPs which can mimic paid work and mitigate the generally harmful effects of unemployment on well-being. Indeed, ALMPs often affect the experience of unemployment by enabling the unemployed to acquire skills and experiences, to meet new people and to acquire a daily structure (Wulfgramm, 2011a; Sage, 2013; Carter and Whitworth, 2017,

${ }^{8}$ The unemployment rate, as we know, is often used as an index of well-being in the labor market, although its effect can, in principle, be neutralized by employment insurance. In addition, there may be a link between the unemployment rate and broader measures of well-being in the labor market.

9 i) the Anglo-Saxon countries (Canada, Ireland, United Kingdom, United States, Australia and New-Zealand) are distinguished by high incomes, low unemployment rates and short unemployment tenure; ii) the Scandinavian countries (Denmark, Finland, Norway and Sweden) stand out with relatively high incomes and a strong but efficient social protection system, combined with low unemployment rates; iii) the countries of Continental Europe (Austria, Belgium, France, Luxembourg, Germany and the Netherlands) stand out with lower incomes than those of Anglo-Saxon countries and high unemployment rates; iv) Mediterranean countries (Italy, Portugal, Spain and Greece) stand out with low incomes and high unemployment rates and the Other group (Czech republic, Estonia, Israel, Poland, Slovenia, Switzerland, Latvia, Lithuania and Slovakia) which has heterogeneous characteristics in terms of incomes, ALMP expenditure and unemployment rate. 
Sage, 2018). Furthermore, ALMPs help the long-term unemployed maintain their human capital, and even their productive capacity, and improve their position in the queue for access to jobs. From this perspective, it is generally accepted that participation in ALMPs has positive effects on the subjective well-being of the unemployed (Carter and Whitworth, 2017; Sage, 2018; Rose, 2019; PuigBarrachina et al., 2020). Generally, ALMPs aim to improve the social and economic life of the unemployed by creating a life situation that has typical psychosocial characteristics (time structure, social contacts, participation for collective ends, status and identity). ${ }^{10}$

Second, we examined whether some type of ALMPs are more effective i.e. that they could have differential effects on the subjective well-being. Our results indicate that incentive employment programs, start-up incentives and training have proven to be the most effective in improving the well-being of the unemployed. This suggests that these programs contribute to creating comfort through funding or income, providing societal support, respecting certain labor standards, and increased stimulation through work (physical or mental effort). In particular, we show that the direct job creation programs are likely to reduce the subjective well-being of the unemployed. This result could be explained by the risk of reducing the intensity (effort) of the research induced by this program, thereby limiting the employment opportunities of beneficiaries and creating negative locking-in effects on the individual's research behavior during the period of participation in the program. Likewise, measures aimed at promoting the integration into the labor market of "unemployable" people, e.g. supported employment and rehabilitation, fall outside the scope of ALMPs and refer to social policy, even social integration. Therefore, the insignificant effect on the well-being of the unemployed is unambiguous.

Comparing these types of ALMPs is used to guide government policy interventions and decisions. This raises two recommendations. First, all ALMPs must be created in order to increase the well-being of the unemployed. This implies that the well-being of the unemployed person must be considered as an indispensable criterion in the analysis, design and evaluation of the other policies (direct job creation and supported employment and rehabilitation) which do not show expected effects, which requires their revision and improvement.

Second, governments must make the right decisions about society by contributing more meaningfully to the well-being of citizens from public policies based on democratic bases. It should be noted that policy-makers need to design and implement a new public policy aimed specifically at increasing the well-being of the unemployed.

\footnotetext{
${ }^{10}$ Jahoda (1982), Knabe, Schöb and Weimann (2016), Pholan (2019).
} 


\section{References}

AISEN, A. - VEIGA, F. J. (2013): How Does Political Instability Affect Economic Growth? European Journal of Political Economy, 29, pp. $151-167$.

ALATARTSEVA, E. - BARYSHEVA, G. (2015): Well-being: Subjective and Objective Aspects. Procedia-Social and Behavioral Sciences, 166, pp. $36-42$.

ANDERSEN, S. (2009): Unemployment and Subjective Well-being: A Question of Class? Work and Occupations, 36, No. 1, pp. $3-25$.

ANDERSEN, S. H. (2008): The Short- and Long-term Effects of Government Training on Subjective Well-being. European Sociological Review, 24, No. 4, pp. $451-462$.

ARELLANO, M. - BOVER, O. (1995): Another Look at the Instrumental Variable Estimation of Error-components Models. Journal of Econometrics, 68, No. 1, pp. 29 - 51.

AUDHOE, S. S. - HOVING, J. L. - SLUITER, J. K. - FRINGS-DRESEN, M. H. (2010): Vocational Interventions for Unemployed: Effects on Work Participation and Mental Distress. A Systematic Review. Journal of Occupational Rehabilitation, 20, No. 1, pp. 1 - 13.

BALLAS, D. - TRANMER, M. (2012): Happy People or Happy Places? A Multilevel Modeling Approach to the Analysis of Happiness and Well-being. International Regional Science Review, 35 , No. 1, pp. $70-102$.

BEHLE, H. (2005): Moderators and Mediators on the Mental Health of Young Participants in Active Labour Market Programmes: Evidence from East and West Germany. International Review of Psychiatry, 17, No. 5, pp. $337-345$.

BLANCHFLOWER, D. G. - OSWALD, A. J. (2008): Hypertension and Happiness across Nations. Journal of Health Economics, 27, No. 2, pp. 218 - 233.

BLUNDELL, R. - BOND, S. (1998): Initial Conditions and Moment Restrictions in Dynamic Panel Data Models. Journal of Econometrics, 87, No. 1, pp. $115-143$.

BOLTON, W. - OATLEY, K. (1987): A Longitudinal Study of Social Support and Depression in Unemployed Men. Psychological Medicine, 17, No. 2, pp. 453 - 460.

BONIN, H. - RINNE, U. (2014): 'Beautiful Serbia' - Objective and Subjective Outcomes of Active Labour Market Policy in a Transition Economy. Economics of Transition, 22, No. 1, pp. 43 - 67.

BONOLI, G. (2010): The Political Economy of Active Labor-market Policy. Politics - Society, 38, No. 4 , pp. $435-457$.

BOUIS, R. - RENNE, J. P. (2006): Caractéristiques des marchés du travail dans les pays de l'OCDE. Economie et prévision, No. 2, pp. $171-178$.

BREIDAHL, K. N. - CLEMENT, S. L. (2010): Does Active Labour Market Policy Have an Impact on Social Marginalization? Social Policy - Administration, 44, No. 7, pp. 845 - 864.

BROOM, D. H. - D'SOUZA, R. M. - STRAZDINS, L. - BUTTERWORTH, P. - PARSLOW, R. - RODGERS, B. (2006): The lesser Evil: Bad Jobs or Unemployment? A Survey of Mid-aged Australians. Social Science - Medicine, 63, No. 3, pp. 575 - 586.

CALIENDO, M. (2009): Start-up Subsidies in East Germany: Finally, a Policy that Works? International Journal of Manpower, 30, No. 7, pp. $625-647$.

CALIENDO, M. - KRITIKOS, A. S. (2010): Start-ups by the Unemployed: Characteristics, Survival and Direct Employment Effects. Small Business Economics, 35, No. 1, pp. 71 - 92.

CALIENDO, M. - SCHMIDL, R. (2016): Youth Unemployment and Active Labor Market Policies in Europe. IZA Journal of Labor Policy, 5, No. 1, p. 1.

CARD, D. - KLUVE, J. - WEBER, A. (2010): Active Labour Market Policy Evaluations: A Metaanalysis. The Economic Journal, 120, No. 548, pp. F452 - F477.

CARD, D. - KLUVE, J. - WEBER, A. (2018): What Works? A Meta-analysis of Recent Active Labor Market Program Evaluations. Journal of the European Economic Association, 16, No. 3, pp. $894-931$.

CARROLL, N. (2007): Unemployment and Psychological Well-being. Economic Record, 83, No. 262, pp. $287-302$. 
CARTER, E. - WHITWORTH, A. (2017): Work Activation Regimes and Well-being of Unemployed People: Rhetoric, Risk and Reality of Quasi-marketization in the UK Work Programme. Social Policy - Administration, 51, No. 5, pp. 796 - 816.

CLARK, A. E. - OSWALD, A. J. (1994): Unhappiness and Unemployment. The Economic Journal, 104, No. 424, pp. $648-659$.

CLARK, A. - KNABE, A. - RÄTZEL, S. (2010): Boon or Bane? Others' Unemployment, Wellbeing and Job Insecurity. Labour Economics, 17, No. 1, pp. $52-61$.

COUTTS, A. P. - STUCKLER, D. - CANN, D. J. (2014): The Health and Wellbeing Effects of Active Labor Market Programs. Wellbeing: A Complete Reference Guide, pp. 1 - 18.

CREED, P. A. (1998): Improving the Mental and Physical Health of Unemployed People: Why and How? Medical Journal of Australia, 168, No. 4, pp. $177-178$.

CREED, P. A. - BLOXSOME, T. D. - JOHNSTON, K. (2001): Self-esteem and Self-efficacy Outcomes for Unemployed Individuals Attending Occupational Skills Training Programs. Community, Work - Family, 4, No. 3, pp. $285-303$.

CREED, P. A. - MACHIN, M. A. - HICKS, R. E. (1999): Improving Mental Health Status and Coping Abilities for Long-term Unemployed Youth Using Cognitive-behaviour Therapy-based Training Interventions. Journal of Organizational Behavior, 20, No. 6, pp. 963 - 978.

CROST, B. (2016): Can Workfare Programs Offset the Negative Effect of Unemployment on Subjective Well-being? Economics Letters, 140, pp. 42 - 47.

DAGUERRE, A. - ETHERINGTON, D. (2009): Active Labour Market Policies in International Context: What Works Best? Lessons for the UK. Department for Work and Pensions, HMSO.

DEATON, A. (2008): Income, Health, and Well-being around the World: Evidence from the Gallup World Poll. Journal of Economic Perspectives, 22, No. 2, pp. 53 - 72.

DEEMING, C. (2013): Addressing the Social Determinants of Subjective Wellbeing: The Latest Challenge for Social Policy. Journal of Social Policy, 42, No. 3, pp. $541-565$.

DIENER, E. - RYAN, K. (2009): Subjective Well-being: A General Overview. South African Journal of Psychology, 39, No. 4, pp. $391-406$.

DOLAN, P. - METCALFE, R. (2012): Measuring Subjective Wellbeing: Recommendations on Measures for Use By National Governments. Journal of Social Policy, 41, No. 2, pp. 409 - 427.

DOLAN, P. - LAYARD, R. - METCALFE, R. (2011): Measuring Subjective Well-being for Public Policy. London: Office for National Statistics, p. 19.

DOLAN, P. - PEASGOOD, T. - WHITE, M. (2008): Do We Really Know What Makes Us Happy? A Review of the Economic Literature on the Factors Associated with Subjective Well-being. Journal of Economic Psychology, 29, No. 1, pp. 94 - 122.

DONOVAN, A. - ODDY, M. - PARDEO, R. - ADES, A. (1986): Employment Status and Psychological Well-being: A Longitudinal Study of 16-year-old School Leavers. Journal of Child Psychology and Psychiatry, 2, No. 7(1), pp. $65-76$.

EALES, M. J. (1989): Shame among Unemployed Men. Social Science - Medicine, 28, No. 8, pp. $783-789$.

EASTERLIN, R. A. - ANGELESCU, L. - ZWEIG, J. S. (2011): The Impact of Modern Economic Growth on Urban-rural Differences in Subjective Well-being. World Development, 39, No. 12, pp. $2187-2198$.

EICHHORN, J. (2014): The (non-) Effect of Unemployment Benefits: Variations in the Effect of Unemployment on Life-satisfaction between EU Countries. Social Indicators Research, 119, No. 1 , pp. $389-404$.

ESCUDERO, V. (2018): Are Active Labour Market Policies Effective in Activating and Integrating low- Skilled Individuals? An International Comparison. IZA Journal of Labor Policy, 7, No. 1 , pp. $1-26$.

FORSLUND, A. - FREDRIKSSON, P. - VIKSTRÖM, J. (2011): What Active Labor Market Policy Works in a Recession? Nordic Economic Policy Review, 1, No. 2011, pp. 171 - 201.

GALLIE, D. - PAUGAM, S. (2000): The Experience of Unemployment in Europe: The Debate. Age, 15, No. 24, pp. $12-19$. 
GOULAS, E. - ZERVOYIANNI, A. (2018): Active Labour-market Policies and Output Growth: Is There a Causal Relationship? Economic Modelling, 73, pp. $1-14$.

GUNDERT, S. - HOHENDANNER, C. (2015): Active Labour Market Policies and Social Integration in Germany: Do 'One-Euro-Jobs' Improve Individuals' Sense of Social Integration? European Sociological Review, 31, No. 6, pp. 780 - 797.

HAGQUIST, C. - STARRIN, B. (1996): Youth Unemployment and Mental Health-gender Differences and Economic Stress. Scandinavian Journal of Social Welfare, 5, No. 4, pp. 215 - 228.

HELLIWELL, J. F. - LAYARD, P. R. - SACHS, J. (eds) (2016): World Happiness Report 2016 Update. Sustainable Development Solutions Network.

HETSCHKO, C. - SCHÖB, R. - WOLF, T. (2016): Income Support, (un-) Employment and Wellbeing. [CESifo Working Paper Series from CESifo, No. 6016.]

HOWARTH, R. B. - KENNEDY, K. (2016): Economic Growth, Inequality, and Well-being. Ecological Economics, 121, pp. 231 - 236.

HUR, H. (2019): Government Expenditure on Labour Market Policies in OECD Countries: Responding to the Economic Crisis. Policy Studies, 40, No. 6, pp. $585-608$.

IVANOV, B. - PFEIFFER, F. - POHLAN, L. (2020): Do Job Creation Schemes Improve the Social Integration and Well-being of the Long-term Unemployed? Labour Economics, 64, pp. 101836.

JAHODA, M. (1982): Employment and Unemployment: A Social-psychological Analysis. Vol. 1. CUP Archive.

JAHODA, M. - LAZARSFELD, P. F. - ZEISEL, H. (1971): Marienthal, the Sociography of an Unemployed Community Chicago: Aldine-Atherton.

JEFFERIS, B. J. - NAZARETH, I. - MARSTON, L. - MORENO-KUSTNER, B. - BELLÓN, J. Á. - SVAB, I. ... - VICENTE, B. (2011): Associations between Unemployment and Major Depressive Disorder: Evidence from an International, Prospective Study (the predict cohort): Social Science - Medicine, 73, No. 11, pp. 1627 - 1634.

KACAPYR, E. (2008): Cross-country Determinants of Satisfaction with Life. International Journal of Social Economics, 35, No. 6, pp. $400-416$.

KLUVE, J. (2010): The Effectiveness of European Active Labor Market Programs. Labour Economics, 17 , No. 6, pp. $904-918$.

KLUVE, J. - CARD, D. - FERTIG, M. - GÓRA, M. - JACOBI, L. - JENSEN, P. ... SCHMIDT, C. M. (2007): Active Labor Market Policies in Europe: Performance and Perspectives. Springer Science - Business Media.

KNABE, A. - SCHÖB, R. - WEIMANN, J. (2016): Partnership, Gender, and the Well-being Cost of Unemployment. Social Indicators Research, 129, No. 3, pp. 1255 - 1275.

KORPI, T. (1997): Is Utility Related to Employment Status? Employment, Unemployment, Labor Market Policies and Subjective Well-being among Swedish Youth. Labour Economics, 4, No. 2, pp. $125-147$.

KRAUSE, A. (2013): Don't Worry, Be Happy? Happiness and Reemployment. Journal of Economic Behavior - Organization, 96, pp. $1-20$.

LINDSAY, C. - MCQUAID, R. W. - DUTTON, M. (2007): New Approaches to Employability in the UK: Combining 'Human Capital Development and 'Work First'Strategies? Journal of Social Policy, 36, No. 4, pp. $539-560$.

LUCAS, R. E. - CLARK, A. E. - GEORGELLIS, Y. - DIENER, E. (2004): Unemployment Alters the Set Point for Life Satisfaction. Psychological Science, 15, No. 1, pp. $8-13$.

MARTIN, J. P. (2015): Activation and Active Labour Market Policies in OECD Countries: Stylised Facts and Evidence on Their Effectiveness. IZA Journal of Labor Policy, 4, No. 1, p. 4.

MCKEE-RYAN, F. - SONG, Z. - WANBERG, C. R. - KINICKI, A. J. (2005): Psychological and Physical Well-being during Unemployment: A Meta-analytic Study. Journal of Applied Psychology, 90, No. 1, p. 53.

MORGAN, R. - O'CONNOR, K. J. (2019): Labor Market Policy and Subjective Well-being during the Great Recession. [GLO Discussion Paper, No. 372.] 
MURPHY, G. C. - ATHANASOU, J. A. (1999): The Effect of Unemployment on Mental Health. Journal of Occupational and Organizational Psychology, 72, No. 1, pp. 83 - 99.

NORDENMARK, M. - STRANDH, M. (1999): Towards a Sociological Understanding of Mental Well-being among the Unemployed: The Role of Economic and Psychosocial Factors. Sociology, 33, No. 3, pp. $577-597$.

NORSTRÖM, T. - GRÖNQVIST, H. (2015): The Great Recession, Unemployment and Suicide. J Epidemiol Community Health, 69, No. 2, pp. 110 - 116.

OSWALD, A. J. (1997): Happiness and Economic Performance. The Economic Journal, 107, No. 445, pp. $1815-1831$.

PAUL, K. I. - MOSER, K. (2009): Unemployment Impairs Mental Health: Meta-analyses. Journal of Vocational Behavior, 74, No. 3, pp. $264-282$.

PECK, J. - THEODORE, N. (2000): Commentary. 'Work First': Workfare and the Regulation of Contingent Labour Markets. Cambridge Journal of Economics, 24, No. 1, pp. $119-138$.

POHLAN, L. (2019): Unemployment and Social Exclusion. Journal of Economic Behavior Organization, 164 , pp. $273-299$.

PUIG-BARRACHINA, V. - GIRÓ, P. - ARTAZCOZ, L. - BARTOLL, X. - CORTÉS-FRANCH, I. - FERNÁNDEZ, A. ... - BORRELL, C. (2020): The Impact of Active Labour Market Policies on Health Outcomes: A Scoping Review. European Journal of Public Health, 30, No. 1, pp. 36 - 42.

PULTZ, S. - TEASDALE, T. W. (2017): Unemployment and Subjective Well-being: Comparing Younger and Older Job Seekers. Scandinavian Journal of Work and Organizational Psychology, 2, No. 1, p. 10.

RAM, R. (2009): Government Spending and Happiness of the Population: Additional Evidence from Large Cross-country Samples. Public Choice, 138, No. 3, pp. 483 - 490.

REINE, I. - NOVO, M. - HAMMARSTRÖM, A. (2011): Is Participation in Labour Market Programmes Related to Mental Health? Results from a 14-year Follow-up of the Northern Swedish Cohort. Scandinavian Journal of Public Health, 39, No. 1, pp. $26-34$.

RITCHIE, H. - CASEBOURNE, J. - RICK, J. (2005): Understanding Workless People and Communities: A Literature Review, No. 255: Corporate Document Services.

ROODMAN, D. (2009): How to Do xtabond2: An Introduction to Difference and System GMM in Stata. The Stata Journal, 9, No. 1, pp. $86-136$.

ROSE, D. (2019): The Impact of Active Labour Market Policies on the Well-being of the Unemployed. Journal of European Social Policy, 29, No. 3, pp. $396-410$.

ROVELLI, R. - BRUNO, R. L. (2008): Labor Market Policies, Institutions and Employment Rates in the EU-27. [IZA Discussion Paper Series, No. 3502.]

SAGE, D. (2013): Activation, Health and Well-being: Neglected Dimensions? International Journal of Sociology and Social Policy, 33, No. 1/2, pp. $4-20$.

SAGE, D. (2015a): Do Active Labour Market Policies Promote the Subjective Well-being of the Unemployed? Evidence from the UK National Well-being Programme. Journal of Happiness Studies, 16, No. 5, pp. $1281-1298$.

SAGE, D. (2015b): Do Active Labour Market Policies Promote the Well-being, Health and Social Capital of the Unemployed? Evidence from the UK. Social Indicators Research, 124, No. 2, pp. $319-337$.

SAGE, D. (2018): Reversing the Negative Experience of Unemployment: A Mediating Role for Social Policies? Social Policy - Administration, 52, No. 5, pp. 1043 - 1059.

SAHNOUN, M. - ABDENNADHER, C. (2018a): The Assessment of Active Labor Market Policies: Evidence from OECD Countries. Economia Politica, 35, No. 2, pp. 257 - 283.

SAHNOUN, M. - ABDENNADHER, C. (2018b): The Efficiency of Active Labor Market Policies: A Comparative Analysis of Tunisia and OECD Countries'. International Economic Journal, pp. $1-21$.

SAHNOUN, M. - ABDENNADHER, C. (2020): A Simultaneous-equation Model of Active Labour Market Policies and Change in Unemployment Rate: Evidence from OECD Countries. Policy Studies, pp. $1-18$. 
SAHNOUN, M. - ABDENNADHER, C. (2021): Returns to Investment in Education in the OECD Countries: Does Governance Quality Matter? Journal of the Knowledge Economy, pp. 1 - 24.

STEVENSON, B. - WOLFERS, J. (2008): Economic Growth and Subjective Well-being: Reassessing the Easterling Paradox. [National Bureau of Economic Research, No. w14282.]

STIGLITZ, J. E. - SEN, A. K. - FITOUSSI, J. P. (2009): Report by the Commission on the Measurement of Economic Performance and Social Progress, p. 292.

STRANDH, M. (2001): State Intervention and Mental Well-being among the Unemployed. Journal of Social Policy, 30, No. 1, pp. $57-80$.

STRANDH, M. - HAMMARSTRÖM, A. - NILSSON, K. - NORDENMARK, M. - RUSSEL, H. (2013): Unemployment, Gender and Mental Health: The Role of the Gender Regime. Sociology of Health - Illness, 35, No. 5, pp. $649-665$.

STUCKLER, D. - BASU, S. - SUHRCKE, M. - COUTTS, A. - MCKEE, M. (2009): The Public Health Effect of Economic Crises and Alternative Policy Responses in Europe: An Empirical Analysis. The Lancet, 374, No. 9686, pp. $315-323$.

VAN DER MEER, T. - TOLSMA, J. (2014): Ethnic Diversity and Its Effects on Social Cohesion. Annual Review of Sociology, 40, No. 1, pp. 459 - 478.

VINOKUR, A. D. - SCHUL, Y. - VUORI, J. - PRICE, R. H. (2000): Two Years after a Job Loss: Long-term Impact of the JOBS Program on Reemployment and Mental Health. Journal of Occupational Health Psychology, 5, No. 1, p. 32.

VUORI, J. - SILVONEN, J. - VINOKUR, A. D. - PRICE, R. H. (2002): The Työhön Job Search Program in Finland: Benefits for the Unemployed with Risk of Depression or Discouragement. Journal of Occupational Health Psychology, 7, No. 1, p. 5.

WADDELL, G. - BURTON, A. K. (2006): Is Work Good for Your Health and Well-being? The Stationery Office, p. 246.

WADSWORTH, M. E. - MONTGOMERY, S. M. - BARTLEY, M. J. (1999): The Persisting Effect of Unemployment on Health and Social Well-being in Men Early in Working Life. Social Science - Medicine, 48, No. 10, pp. 1491 - 1499.

WANBERG, C. R. (2012): The Individual Experience of Unemployment. Annual Review of Psychology, 63, pp. $369-396$.

WOLFF, J. - STEPHAN, G. (2013): Subsidized Work before and after the German Hartz Reforms: Design of Major Schemes, Evaluation Results and Lessons Learnt. IZA Journal of Labor Policy, 2, No. 1, p. 16.

WULFGRAMM, M. (2011a): Can Activating Labour Market Policy Offset the Detrimental Life Satisfaction Effect of Unemployment? Socio-Economic Review, 9, No. 3, pp. 477 - 501.

WULFGRAMM, M. (2011b): Subjektive Auswirkungen aktivierender Arbeitsmarktpolitik: EinEuro-Jobs als sozialintegrative Maßnahme? Zeitschrift für Sozialreform, 57, No. 2, pp. 175 - 198.

WULFGRAMM, M. (2014): Life Satisfaction Effects of Unemployment in Europe: The Moderating Influence of Labour Market Policy. Journal of European Social Policy, 24, No. 3, pp. 258 - 272.

YOUNG, C. (2012): Losing a Job: The Nonpecuniary Cost of Unemployment in the United States. Social Forces, 91, No. 2, pp. $609-634$. 


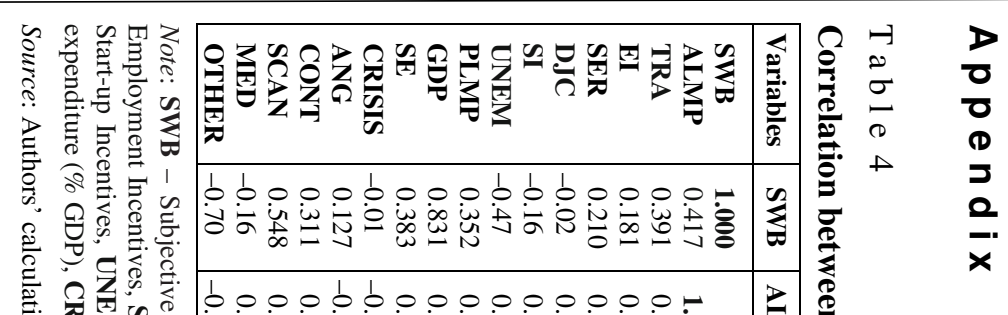

政

\begin{tabular}{|c|c|}
\hline 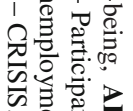 & 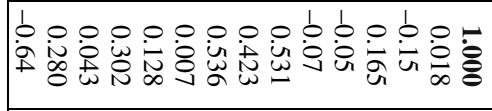 \\
\hline 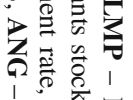 & 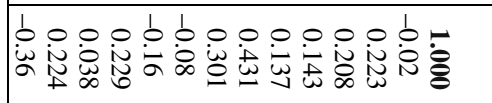 \\
\hline 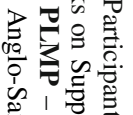 & 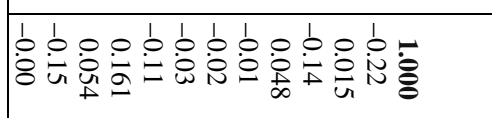 \\
\hline 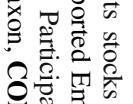 & 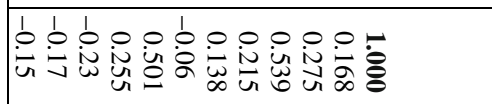 \\
\hline $\begin{array}{ll}0 \\
0\end{array}$ & 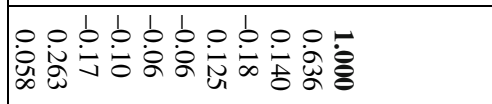 \\
\hline 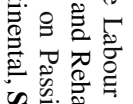 & 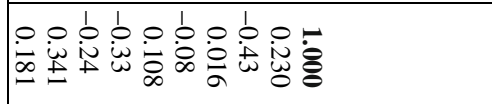 \\
\hline 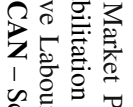 & 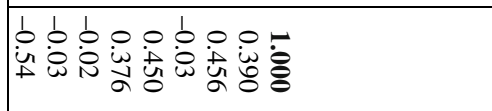 \\
\hline 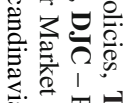 & 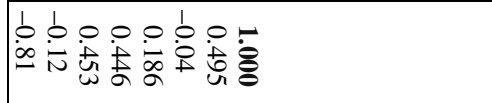 \\
\hline 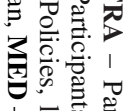 & 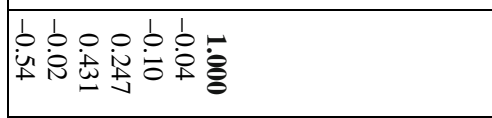 \\
\hline 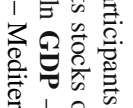 & 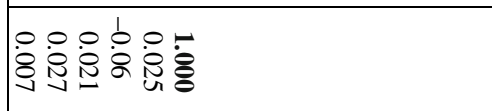 \\
\hline 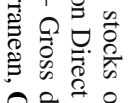 & 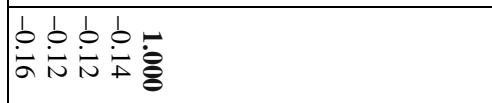 \\
\hline 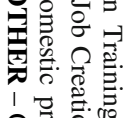 & 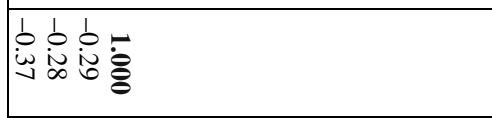 \\
\hline 20 & 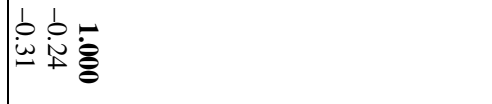 \\
\hline 跑: & 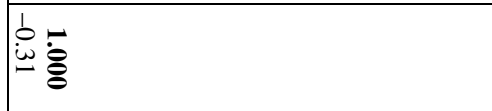 \\
\hline $\begin{array}{ll}1 & 0 \\
0 & 0 \\
n & 0 \\
0\end{array}$ & 言 \\
\hline
\end{tabular}

